\title{
The Effect of Timely Interference of English Language Teachers on the Improvement of Learners' Oral Performance
}

\author{
Ibrahim Mohammed Al-Faki \\ Wadi Al-Neel University-Sudan \\ King Abdu-Al-Aziz University - KSA
}

Ahmed Gumaa Siddiek (Corresponding Author)

Shaqra University P.O.Box 18 - Community College

Dawadami - KSA 11911

Tel: +966536872406 E-mail: aahmedgumaa@yahoo.com

Received: 04-07-2013

doi:10.7575/aiac.ijalel.v.2n.6p.222
Accepted: 18-09-2013

Published: 01-11-2013

URL: http://dx.doi.org/10.7575/aiac.ijalel.v.2n.6p.222

\begin{abstract}
Corrective feedback or error correction techniques are two terms interchangeably used to mean the interfering of language teachers to correct errors committed by their students. The issue has been controversially debated over the time. Many teachers support the view of immediate interference to correct learners' error. These are the old disciples of teacher-based theory in education, while others defend the idea of student-centered education. This paper aims to pool the efforts of both schools; but the researchers prefer the timely interference of the instructor to correct his/her student's error. The researchers believe that, this may be the practical way to modify learners' oral language errors. The word timely should be relatively understood to simply mean that teachers should decide the well-timed moment to get involved in the learning process. The teacher is the master of the place and time of the whole teaching environment, so s/he will have to soundly judge their interference by considering: 1 . The vitality of the text 2 . The degree of the criticality of the context. 3. The sound calculation of the possibility of loss OR gain if the interference is not well-timed.
\end{abstract}

Keywords: corrective error, feedback, teacher interference, ELT

\section{Introduction}

There has been an increasing interest in investigating corrective feedback role in second language acquisition over the last decades and several definitions have been provided since then. The terms negative evidence and corrective feedback are interchangeably used by some researchers. However, the former is used mainly in the field of language acquisition, whereas the latter is preferred in language teaching. Long (1996), views feedback as both: negative evidence as well as a positive one. Feedback is said to be positive evidence when we provide learners with grammatical, acceptable models in the target language; and negative evidence is when we provide learners with direct or indirect information of what is unacceptable. Lightbown and Spada (1999) see corrective feedback as any indication to the learners that their use of the target language is incorrect. For the sake of convenience, in this paper the term corrective feedback and error correction techniques are used interchangeably in this sense, however, the abbreviation (CF) will be used to represent the former.

The role and the importance of CF have been debated on theoretical and pedagogical grounds. Whereas some language acquisition theories and second language teaching methodologies question the use of CF, there are others which favour its use and see it as beneficial. Teachers of second or foreign languages, however, sometimes are unaware of these issues and their views towards corrective feedback and, consequently, their practice in the classroom can be affected by the lack of knowledge as reported by Méndez (2013), that the lack of knowledge can be seen in the mismatch between teachers' preference and what learners really want their teachers to use in the classroom. It can also be seen in misuse of these techniques which may result in unenthusiastic students.

Some identified problems, regarding teaching foreign languages and the uses or lacks of corrective feedback are due to the inconsistency, ambiguity, and ineffectiveness of teachers' corrections (Chaudron, 1977; Long,). According to Lyster and Mori (2006), many teachers have been found to adopt ambiguous and unsystematic corrective feedback techniques or approaches. Sometimes they accept errors for fear of interrupting the communicative flow, and at other times they correct the same errors many times. Lyster and Ranta (1997) also observed that the teachers' correction targeted on a wide range of learner error leading to an overwhelming linguistic data in the form of corrective feedback, which means an overload for learners' cognitive capacities. Therefore, teachers are encouraged to systematize the use of CF. This study therefore aims at investigating the types of oral corrective feedback that English language teachers use at different 
levels of schooling, comparing their attitudes about corrective feedback techniques and their actual performance in their classrooms.

\subsection{Statement of the Problem}

The problems stems from our observations of some EL teachers in the field, doing unsatisfactory language teaching. Their teaching practice has- consequently - yielded poorly-trained language users; with clear weaknesses in oral communication. We often notice the poor performance of these language users - in the Arab region - in their oral interaction with others. We can often notice the tangible weak performance of our graduates when communicating in English or handling business issues with foreigners in many places or when they are situationally obliged to interact with visitors at airports, in hotel receptions, bank transactions or simply making telephone calls.

Through our long teaching experience with teachers in classes, we notice that there is too much or too little interference of teachers in correcting students' errors. Both techniques may have negative results on the learner. Now we are tackling this subject by referring to literature and previous studies carried out by many researches in the field of language teaching and learning. These researchers believe that learners can benefit if the correction is given in appropriate amount and it will surely contribute positively to students' learning (Carroll \& Swain, 1993; Han, 2002; Richards \& Lockhart,1994; Sinclair \& Brazil, 1982; Tsui, 1995; White, 1993). Moreover, Lyster \& Ranta, 1997; Harmer, 1991), believe that certain number of oral corrective feedback techniques common to the language classroom practice.

The researchers aim by these efforts to raise awareness among language teachers and provide information about various oral corrective feedback techniques; that can be used by teachers to correct their students' immediate speaking errors in the classroom.

\subsection{Research Questions}

This research aims to find answers to the following questions:

1. What types of oral correction techniques do English teachers usually implement in different teaching environments?

2. Is there any discrepancy in teachers' attitudes about oral corrective feedback and their actual practice?

3. What types of oral corrective feedback do students usually expect from their teachers?

\subsection{Objective of the survey}

English Language teachers use different techniques of oral correction to boost students' learning. One of the objectives of this paper is to examine these types of oral correction techniques, those English Language teachers in - general - use at different teaching situations. We are keen to find out if there is any relationship between teachers 'beliefs and their oral corrective feedback, compared with their actual practice in the classroom. In addition, we also aimed to identify the types of oral corrective feedback that students mostly prefer to be used by their instructors.

\subsection{Significance of the Study}

EL teachers all over the globe often spend a significant amount of the class time giving oral corrective feedback. This time is expected to be spent in the wisest possible way. For this to happen, teachers should not be left to their own intuitions or discretion, as some of them lack enough experience to judge the right time and place to interfere in their student's learning process. Such teachers should be given advice to do their daily routine in principled manner. Many teachers currently follow the same inherited techniques of teaching from their old teachers and they vehemently defend this practice. But in order for things to change to the better, it is important to make these understand the situation by assimilating the new trends in language education and language acquisition. Based on this understanding, they can make sound decisions.

We hope the result of this survey will improve the environment of interaction between teachers and students. Furthermore, we will pay attention to students to make them understand the reasons their teachers sometimes need to interfere in their oral communication. It is assumed that, without teachers' correction, students will not realize if their utterances are correct; and that, this correction is intended to gradually lead them to use better English in the future.

\subsection{Methodology}

This is a historical and analytical survey intended to review efforts of theorists, educators and teachers in corrective feedback. This review practically entailed a wide range of reading to navigate many places and consult many authoritative references by referring to many articles and research in books, periodicals and theses to collect evidence to enrich this discussion.

\section{Discussion: Defining Feedback}

Many terms are used in identifying errors and providing CF in the SLA literature. Among the most common are corrective feedback, negative evidence, and negative feedback. Because of possible confusion arising from the use of this terminology, brief reviews of the definitions of terms and of the different types of feedback are presented below. Chaudron (1988) stated that that the term corrective feedback incorporates different layers of meaning. According to him, the term "treatment of error" may simply refer to "any teacher behaviour following an error that minimally attempts to inform the learner of the fact of error" Lightbown and Spada (1999) define corrective feedback as: 
Any indication to the learners that their use of the target language is incorrect'”. This

includes various responses that the learners receive. When a language learner says,

'He go to school every day', corrective feedback can be explicit, for example, 'no, you

should say goes, not go' or implicit 'yes he goes to school every day', and may or may

not include metalinguistic information, for example, 'Don't forget to make the verb

agree with the subject'. (p. 171-172)

According to Schachter (1991), corrective feedback, negative evidence, and negative feedback are three terms used respectively in the fields of language teaching, language acquisition, and cognitive psychology. Different researchers often use these terms interchangeably. The feedback can be explicit (e.g., grammatical explanation or overt error correction) or implicit. Implicit correction includes, but is not limited to, confirmation checks, repetitions, recasts, clarification requests, silence, and even facial expressions that express confusion.

Long (1996) offers a more comprehensive view of feedback in general. He suggests that environmental input can be thought of in terms of two categories that are provided to the learners about the target language (TL): positive evidence and negative evidence. Long defines positive evidence as providing the learners with models of what is grammatical and acceptable in the TL; and negative evidence as providing the learners with direct or indirect information about what is unacceptable. This information may be explicit (e.g., grammatical explanation or overt error correction) or implicit (e.g., failure to understand, incidental error correction in a response, such as a confirmation check, which reformulates the learners' utterance without interrupting the flow of the conversation - in which case, the negative feedback simultaneously provides additional positive evidence, and perhaps also the absence of the items in the input. (p. 413)

McNamara (1999) and Ur (1996) define 'feedback' as 'passing some information to the students about their performances". It is also defined as the comments or other information that students receive from their teachers or from other people concerning their success in learning (Coulthard, 1992; Tsui, 1995; Cameron 2001). This could be after each response, in a spoken discourse for example, "Well done", "Yes", "Good" for correct answer or by "'Try Again"e, 'Ok, but ..."' or "'Sorry that is wrong', for the wrong answers.

Littlewood (1981) and Lewis (2002) point out that feedback means telling students about their progress and showing them their errors in order to guide them to areas for improvement. In addition, Harmer (2001) mentions that oral feedback should not only be correcting our students' errors but should also be offering them how they can correct these errors. Askew and Lodge (1997), cited in Askew 2000, go further than that as they believe that feedback is much wider than that as it includes any kind of communication that helps learners in every learning experience. Askew and Lodge's definition seems to be more comprehensive. Important things like gestures and facial expressions could be included under this definition and these are, in many speaking events, very vital in making successful interactions.

Overall, we could say that feedback is the message that students receive from their teachers on their oral or written work. This message could be oral or written to show their errors/mistakes and at the same time help them to overcome the error/errors they have made in the future, in a supportive learning environment.

\subsection{The Importance of Oral Feedback}

The Oral feedback has been debated in language acquisition theories and language teaching. The role of $\mathrm{CF}$ in the different theories of language acquisition is not the same and this is reflected in pedagogical implications in the language classrooms. Many writers such as (Littlewood, 1981; Lightbown \& Spada, 1999; Lewis, 2002; Richards, 1994; Ur, 1996) discuss the importance of oral corrective feedback, considering different areas which can be taken into account. It seems that all these writers agree on some issues like the purpose of oral feedback and its effects on teaching and learning. The following is a brief demonstration of these two areas:

2.1.1 Purpose of Oral Feedback

Different writers look at the purpose of oral feedback from different perspectives. For example, Lewis (2002) summarizes the purpose of oral feedback in four points: (1) it provides students with advice about learning and it also helps them to acquire some kind of language input as they might learn new vocabulary and structures in context, (2) it provides information for both teachers and students as it paves ways for teachers to describe their students' language. From students' perspective it is a kind of assessment which is more precise than marks or grades; (3) it is a form of motivation as it can encourage students to study and do their best, and (4) it is one step forward towards self-reliance as students may start detecting their own mistakes.

Moreover, oral feedback could play a key role in helping students improve their English (Askew \& Lodge (1997), cited in Askew, 2000; Lightbown\&Spada, 1999). Researches in which students were given considerable amounts of practice in certain skills and never given oral feedback show fossilization in students' performance (Perrott, 1982). Littlewood (1981) adds that, good oral feedback might help students to define their purpose and focus as it tells students how successful they were and determines the criteria for success.

Furthermore, oral feedback usually aims to help students understand the target performance and to help them compare the target and the current performance i.e. do they say what is expected from them? (Richards, 1994 \& Ur, 1996). In the language classroom, it might direct our students towards the accuracy of what they say. This could happen when teachers correct the errors that should be corrected directly. Students here could notice their errors in order to avoid them next time (Richards, 1994). Feedback might also help students to close the gap between the target and the current performance in order to produce the target responses. Perrott (1982), states that without oral feedback no improvement can be noticed in the students' performance.

As one of the primary functions of teachers is to motivate students in their learning, Lewis (2002) says that oral feedback might motivate students and encourage them to use the language to the best of their abilities taking into 
account whatever the teacher knows about the students' abilities. Richards (1994) agrees with view that as he writes that oral feedback might enhance the motivation of the students through creating an encouraging classroom atmosphere.

Lewis (2002) goes further by indicating that teacher's oral feedback plays a key role in providing the students with a very significant wealth of linguistic information. This might happen when the teacher's words in spoken discourse illustrate how language is used in one to one communication. Schachter (1983, cited in Lynch 1996), believes that feedback might help students to convert the necessary input into actual language learning.

Finally, feedback provides teachers with information about individuals and the whole class as well. Moreover, it highlights the strengths and the weaknesses of each student (Lewis, 2002). Thus, as Brown, McDowell, \& Race (1998) indicate, teachers then could provide their oral feedback according to their students' individual feeling in order to correct their weaknesses or to applaud good students when they provide correct answers.

\subsubsection{The Effect of Oral Feedback on Teaching and Learning}

Oral feedback given to students can be a two edged sword i.e. it may have some pros as well as some cons. According to Brown et al (1998) it is the teacher who can maximize its benefits and minimize the possible dangers. Here is a brief illustration of some of these pros and cons in terms of value and limitation.

\subsubsection{The Value of Oral Feedback \& Oral Correction}

Oral feedback can have many advantages. It might have a very strong effect on learning as it is one of the important ways through which teachers usually assess their students' performance and from which students may benefit (Askew, 2000). Furthermore, it might be more beneficial for the students as it may provide more information through the help of other tools like facial expressions and body language (Brown et al, 1998). In addition, if the teacher asks the students to think again and have another try this, as Fanselow (1987) writes, "'is a way to help them test their own thoughts and hypotheses which might improve their learning strategies.',

On the other hand, Ohta (2001) takes a further corrective feedback a step by showing that if the correct form is provided, learners may have the chance to compare their own production with that of another. In this way, corrective feedback may stimulate hypothesis testing, giving the learner the opportunity to grapple with form-meaning relationships. Corrective feedback that does not provide the correct form, on the other hand, may force the learners to utilize their own resources in constructing a reformulation. In either case, corrective feedback may facilitate L2 development.

Finally, an advantage of oral feedback could be that teachers can see the effect of their feedback on his students and their performance and so can take any action helshe feels necessary as a follow up (Brown et al, 1998).

2.1.4 The Limitations of Oral Feedback

Although oral feedback, as discussed earlier as a number of advantages, it could have a number of limitations too. For example, Lewis (2002) and Brown et al (1998) assert that teachers should be careful when giving oral feedback as students may misunderstand their message and so their feelings might be affected. Another point to consider here is that when giving oral feedback we should avoid spoon-feeding our students to encourage them to be autonomous (Lewis, 2002).

Finally, giving the wrong feedback or even the teacher's failing in considering the task level or students' abilities, might lead to a learning problem. Chambers (1999) explains that although feedback giving is not an easy job, what is more difficult is deciding what feedback should be given bearing in mind the difficulty of the task and the students' abilities.

2.1.5 Corrective Feedback and Types of Errors

As explained earlier by Ellis (1994), Corder (1967) distinguished between "errors" and "mistakes." An error takes place as a result of lack of knowledge (i.e., it represents a gap in competence). A mistake is a performance phenomenon, reflecting processing failures that arise as a result of competing plans, memory limitations, and lack of automaticity. Burt (1975) suggested that teachers should focus on "global" rather than "local errors." Global" errors are errors that affect overall sentence organization. Examples are wrong word order, missing or wrongly placed sentence connectors, and syntactic overgeneralizations. Local errors are errors that affect single elements in a sentence (for example, errors in morphology or grammatical functions). Krashen (1982) argued that Corrective Feedback should be limited to features that are simple and portable (i.e., "rules of thumb"). Others, including (Ellis 1993), have suggested that CF be directed at marked grammatical features or features that learners have shown they have problems with.

When correcting, it is important to identify the type of error the learners make because it is not always the case teachers want or need to correct everything. Errors have been categorized Yoshida, (2008) as:

- Morphosyntactic error. Learners incorrectly use word order, tense, conjugation and particles.

- Phonological error. Learners mispronounce words (or we suggest it could also include suprasegmental errors).

- Lexical error. Learners use vocabulary inappropriately or they code-switch to their first language because of their lack of lexical knowledge.

- Semantic error. Misunderstanding of a learner's utterance, although there is not any grammatical, lexical or phonological error.

2.1.6. Types of Oral Feedback

Different writers classify the types of oral feedback differently. Some classify it into formative and summative while others distinguish between feedback on the content of what students produce and on the form. Others see them as positive and negative oral feedback. In addition, there are writers who classify feedback into explicit feedback and implicit feedback. Finally, there are some writers who may try to be more precise when they make a distinction between 
three types of oral feedback: corrective, strategic and evaluative feedback. The following part is an illustration of these different types with a focus on oral corrective feedback:

\subsubsection{Formative and Summative Feedback}

Hamp-Lyons \&Heasley (1987), and Tsui (1995) suggest two types of oral feedback through which teachers make a judgment about their students' oral work; "the Formative"' and 'the Summative' feedbacks. Formative assessment provides feedback and information during the instructional process, while learning is taking place, and while learning is occurring. Formative assessment measures student progress but it can also assess your own progress as an instructor.

Summative assessment takes place after the learning has been completed and provides information and feedback that sums up the teaching and learning process.

\subsubsection{Feedback on the Content and on the Form}

Richards \& Lockhart (1994) and Harmer (2001) emphasize that teachers tend to focus their oral feedback on how students say something, i.e. the form (correctness of grammar or pronunciation), rather than on the meaning of what they say i.e. the content. According to Richards \& Lockhart (1994), oral feedback should not only be used to let students know how well they have done something but it should also be used to increase students' motivation and build a supportive classroom atmosphere. Lewis (2002) \&Wragg and Brown (1993) support Richards \& Lockhart's point of view and they advise teachers to concentrate their oral feedback on students' communicative abilities as well as the form of what they say.

Richards \& Lockhart (1994: 189) mention seven strategies teachers often use to give feedback on the content of what students say: Acknowledging a correct answer; indicating an incorrect answer; praising; expanding or modifying a student's answer; repeating; summarizing; and criticizing.

\subsubsection{Positive and Negative Oral Feedback}

A number of writers classify oral feedback into "positive" and "negative". For example, McNamara (1999) and Nunan (1991) note that teachers use both techniques in the classroom as an attempt to reinforce good performance and to help weaker students to perform better in their next tries. Nunan (1991) adds that positive oral feedback serves two functions: to draw students' attention that they have done well and to motivate them through praise. Askew \& Lodge (1997), and Lewis (2002) agree with Nunan as they mention that positive oral feedback could be very beneficial for students as it supports learning through making students more motivated and thus work harder to produce correct utterance.

Negative oral feedback, on the other hand, might enhance or hinder learning. This depends on how teachers use this type of oral feedback. Carrol\& Swain (1993) and Forta (1986), cited in Nassaji and Swain (2000), report that negative oral feedback tends to be more effective when it provides the student with detailed information about the errors he/she has made rather than when it only gives him/her some clues and leaves a space for student's inference. Lewis (2002) goes further than that stressing the risky impact that negative oral feedback could cause as he believes that students who always receive negative oral feedback become frustrated which may result in weak performance.

\subsubsection{Explicit and Implicit Oral Feedback}

Oral feedback is also classified into two types according to the way it is delivered to students: explicit and implicit. Loewen (2005) writes that teachers, during focus-on-form instruction, attempt to draw students' attention to language in both ways: implicitly and/or explicitly. Explicit oral feedback occurs when teachers give students clear indications that errors have been made and so students get clear messages of what exactly was wrong in their utterance (Ellis, Loewen, \&Erlam, 2006). On the other hand, implicit oral feedback can have the form of facial signals, paraphrases, and recasts (Han, 2002a; Ellis, 1999).

2.1.11 Strategic, Evaluative, and Corrective Oral Feedbacks

Some writers classify oral feedback used by English teachers in the classroom into these three types of feedbacks (Gattullo, 2000 \& Harmer, 2001). This classification could be an attempt to explain, in some detail, what teachers of English usually do when interacting with their students i.e. teachers usually correct and evaluate their students' oral work and they provide them with techniques to help them overcome the obstacles in their spoken discourse. Here is an overview of some of their viewpoints:

\subsubsection{Oral Strategic Feedback}

Oral strategic feedback includes advice from the teacher to the students on how to get over a problem. In other words, teachers try to provide channels through which they might help their students to overcome their mistakes independently. For example, to help a student say the definite article "'the" the teacher might say to the student "Look at my tongueput your tongue on your teeth- the". Tsui (1995) suggests that using oral strategic feedback can enhance learning as it might help students to be self-reliant as they may start thinking of ways through which they can overcome their own problems following the model of their teacher.

In addition, Lewis (2002) thinks that good oral feedback can be given on students' strategies to encourage them promote these strategies to overcome the possible learning problems they might face. For example, McDevitt (1989) points out those students are unable to identify incorrect sentences they might produce while reading. He suggests that getting them to read their sentences aloud is a technique that may help them realize where the errors are. Moreover, we might also, as Lopes (1998) suggests, develop some other techniques to help our students improve their strategies to tackle the errors they might make. For example, having a card in which a big " $S$ '" is written (representing the third person singular " s") to flash when a related error is spotted. The researcher thinks that Lopes' suggestion could be very practical as it might improve students' abilities in detecting their own errors as well as the errors made by their 
colleagues. This could be one step forwards towards a more learner-centred classroom. However, teachers should be cautious as such a technique might not be suitable for all levels of students.

\subsubsection{Oral Evaluative Feedback}

Oral evaluative feedback, which is dominant in the second and foreign teaching classes (Gattullo, 2000), occurs when the teacher gives a judgment about the quality of his/her students' performances e.g. "Good", "That's right" or 'That's a good try". Lewis (2002) believes that oral feedback, in addition to highlighting the errors to students, should be a technique to point out what has been done well. This kind of oral feedback, similar to the other kinds, could also enhance learning. Harmer (1998) \& McNamara (1999) write that oral evaluative feedback maybe motivating as it might help students to be able to do things better than their first tries.

Harmer (1998) adds that in order for oral feedback to succeed, it needs to provide the students with constructive criticism instead of criticizing them for making errors. Wragg and Brown (1993) agree with Harmer as they state that skilful teachers need to be able to identify both the strengths and weaknesses of their students and provide the students with constructive oral feedback on both sides.

As Harmer (2001) notes that imprecise evaluative feedback might pass the wrong message for the students and so might negatively their motivation in learning. It is to say that oral evaluative feedback is needed to boost students' performance, but it should not be overused. There could be a risk that if oral feedback is overused by the teacher, it might lose its power and thus cannot be used any more to increase students' motivation to learn and to perform better. Thus, teachers should be careful and very precise in selecting the right technique at the right time with the right student. 2.1.14 Oral Corrective Feedback

Another synonym for 'corrective feedback' is 'error correction'. Even though many still use the terms 'corrective feedback' and 'error correction' interchangeably, Allright and Baily (1991) distinguish between the two, arguing that the term 'correction' implies 'cure'. The fact that a teacher has given a corrective feedback does not mean the error has been taken care of for good. The term 'error treatment' simply suggests that the error has been treated in some way irrespective of the outcome of the treatment.

However, corrective feedback aims to help students correct their language use towards the target language and so it is mainly concerned with accuracy. For example, a student might say "Yesterday, I come to school at eight o'clock" so the teacher gives corrective feedback saying "Yesterday, I came to school at eight o'clock". Sometimes, as in the metalinguistic and repetition oral corrective feedback types, oral corrective feedback can help the student to reach the correct form as these types respectively provide him/her with clues and indications of the errors and where exactly they occurred. Ancker (2000) says that teachers should use corrective feedback positively to support their students' target response and their learning.

\subsubsection{Oral Corrective Feedback Strategies}

In their paper, Lyster\&Ranta (1997) list six types of oral corrective feedback that are common to the language classroom: (1) explicit correction, (2) recast, (3) clarification request, (4) metalinguistic feedback, (5) elicitation, and (6) repetition. Harmer (1991:63) uses the terms "echoing", and "expression" for "repetition" and "elicitation". He adds three new types: (1) denial, and (2) questioning (peer-correction and self-correction).Dempsey, Driscoll, and Swindell (1993) regard he cases when the teacher does not give any corrective feedback 'ignoring' as another type of feedback. These ten types make the core discussion of this study. Shujen S. Yao, 2000, cited in Mendez et al, 2010) notices two others: (1) interruption, and (2) body language.

It can be noticed that all these types of oral corrective feedback discussed so far can be categorized under summative and formative types of oral feedback. In addition, each of these types of oral corrective feedback can be used by teachers to comment on both the content of what students produce as well as the form. Regarding explicit and implicit feedback types, four types of oral corrective feedback can be included under explicit type of feedback: (1) explicit correction, (2) metalinguistic feedback, (3) denial, and interruption. Similarly, seven of them can be regarded as implicit feedback types: (1) recasts, (2) clarification request, (3) elicitation, (4) repetition, (5) questioning (peer-correction and self-correction), (6) ignoring, and (7) body language-

\subsubsection{Explicit correction}

Explicit correction is "the explicit provision of the correct form". As the teacher provides the correct form, he or she clearly indicates that what the student had said was incorrect ... (e.g., "Oh, you mean," "You should say") (Lyster and Ranta, 1997: 46). Lasagabaster and Sierra (2005) advise teachers to provide their students with more explicit comprehensible oral corrective feedback. Loewen (2005) highlights that providing students with explicit correction can help them to improve their language implicitly and/ or explicitly. Corder (1967) and Hendrickson (1978) disagree with that as they stress that students could benefit more if their teachers push them in their outputs through implicit error correction rather than providing them with the correct form. We believe that students need to be exposed to both explicit and implicit oral correction techniques as that can help them expand their learning strategies. However, English language teachers need to make appropriate decisions on when to use each of these techniques. They need to keep in mind a number of factors that may rightly lead them to make the right decision. Factors like students' level of English, their background knowledge, the learning environment, how they like to learn and how they learn better are crucial. Teachers also need to decide on which of these techniques to use with an individual learner.

\subsubsection{Recast}

The term recast was initially used in the literature of first language acquisition to refer to responses by adults to children's utterances (Nelson, Carskaddon, \& Bonvillian, 1973; as cited in Nicholas et al, 2001); afterward it merged into the domain of second language acquisition in which different definitions were utilized for this term. 
Lyster and Ranta (1997, p. 46) define recast as "teachers" reformulation of all or part of a student's utterance, minus the error". Ohta (2001: p.141) adds that "recasts are immediately subsequent to the erroneous utterance and that they may contrast with learner's utterances phonologically, morphologically, syntactically, or semantically, but are based on the learner's erroneous utterance and maintain semantic contiguity with it".

According to Ellis and Sheen (2006, pp. 78-80), recasts are of various types including corrective recasts (Doughty \& Varela, 1998), corrective/non-corrective recasts (Farrar, 1992), full/partial recasts, single/multiple recasts, single utterance/extended utterance recasts, and simple/complex recasts (Ellis \& Sheen,2006). Nelson, Denninger, Bonvillian, Kaplan, and Baker (1984) explain that simple and complex recasts that the former deals with minimal changes to the child's utterance while the latter is concerned with providing the child with substantial additions. It is also mentioned that in terms of their linguistic development, children benefit from simple recasts more than complex ones (Nelson et al., 1984).

There is no general agreement among SLA practitioners regarding the effectiveness of recasts due to their limitations. Though some researchers (e.g., Long, 2006; Doughty, 2001) consider recast as an effective corrective feedback technique, others (Lyster, 1998a; Panova\&Lyster, 2002) propose that learners usually pass recasts unnoticed and thus they regard them not as effective for interlangauge development. A number of interaction researchers (e.g., Braidi, 2002; Chaudron, 1977, 1986; Fanselow, 1977; Long, 1996; Lyster, 1998a, 1998b; Lyster\&Ranta, 1997; Nicholas et al., 2001), referring to the ambiguity of recast, also argue that recast might be perceived as synonymous in function as mere repetition for language learners hence learners might fail in perceiving the corrective function of recasts (e.g. Long, 2006; Lyster\&Ranta, 1997; Morris \&Tarone, 2003; Nicholas et al, 2001). Learners might be simply provided with the correct form without being pushed to modify their interlanguage since recasts don't elicit repair (Loewen\&Philp, 2006). In addition, Loewen and Philp (2006), based on previous studies (e.g. Ellis \& Sheen, 2006; Long, 1996; Long, Inagaky, \& Ortega, 1998), affirm that the effectiveness of recasts depends on the targeted form under study. Despite all these limitations, bulky researches on this issue yield evidence for the positive impact of recasts on L2 learning (Amount, 2001; Braidi, 2002; Doughty \& Varela, 1998; Han, 2002; Havana, 2002; Iwashita, 2003; Leman, 2003; Long, Inagaki, \& Ortega, 1998, 1998; , 2000; Philp, 2003). Doughty and Varela (1998) conducted a study on the effectiveness of the corrective recasts and reported that learners who received corrective recasts outperformed the control group in both oral and written measure.

The results of numerous studies revealed that contradictory interpretations of recasts can be attributed to the different contexts in which recasts are implemented (Nicholas et al, 2001), suggesting the ineffectiveness of recasts in classroom setting (e.g. Ellis, Basturkmen, \&Loewen, 2001; Lyster, 1998a, 1998b; Lyster\&Ranta, 1997; Morris \&Tarone, 2003; Nabei\& Swain, 2002; Panova\&Lyster, 2002) and their efficiency in laboratory setting (e.g., Braidi, 2002; Carroll \& Swain, 1993; Han, 2002; Iwashita, 2003; Leeman, 2003; Long et al., 1998).

2:1.18 Clarification Request

Clarification Request is the type of feedback that carries questions indicating that the utterance has been ill-formed or misunderstood and that a reformulation or a repetition is required. This kind of feedback encapsulates "problems in either comprehension, accuracy, or both" (Lyster \& Ranta, 1997, p.47). Clarification requests, unlike explicit error correction and recasts, can be more consistently relied upon to generate modified output from learners since it might not supply the learners with any information concerning the type or location of the error.

2.1.19 Metalinguistic Feedback

Much like explicit error correction, metalingustic feedback- because it diverts the focus of conversation towards rules or features of the target language- falls at the explicit end of the corrective feedback spectrum. Lyster and Ranta (1997: $p$. 47) define it as the feedback that "... involves a teacher making comments or indicating to the students that there is an error in the language output ... (e.g., Can you find your error? And "Is it feminine?")". This type of oral corrective feedback could work more successfully with students of sufficient level of English as it usually contains professional terms.

Lyster and Ranta, (1997) categorize metalingustic feedback as "comments, information, or questions related to the wellformedness of the student's utterance, without explicitly providing the correct form". Unlike its name, the inclusion of metalanguage is not its deterministic characteristics; rather the encoding of evaluations or commentary regarding the non-target-like nature of the learner's utterance is considered as the defining feature. Metalinguistic feedback is divided by (Lyster\&Ranta, 1997) into three subcategories: metalinguistic comments, metalinguistic information and metalinguistic questions.

The least informative one is metalinguistic comments which only indicate the occurrences of an error. But the next subcategory, i.e. metalinguistic information, not only indicates the occurrences or location of the error but also offers some metalanguage that alludes to the nature of the error. Metalinguistic questions, the last identified subcategory of metalinguistic feedback, "point to the nature of the error but attempt to elicit the information from the student" (Lyster \& Ranta, 1997, p.47). This kind of metalinguistic feedback requires learner to reconsider their assumptions regarding the target language form while metalinguistic information applies metalanguage to mark the nature of the error.

2.1.20 Elicitation

Elicitation is a correction technique that prompts the learner to self-correct (Panova \&Lyster, 2002) and may be accomplished in one of three following ways during face-to-face interaction, each of which varies in their degree of implicitness or explicitness. One of these strategies is request for reformulations of an ill-formed utterance. The second one is through the use of open questions. The last strategy which is the least communicatively intrusive and hence the most implicit is the use of strategic pauses to allow a learner to complete an utterance. Therefore, elicitation falls in the 
middle of explicit and implicit continuum of corrective feedback. This kind of corrective feedback is not usually accompanied by other feedback types.

Although Harmer (1991:63) uses the terms "expression" for "elicitation", he also highlights that the teacher in this technique uses techniques like gestures and body language to indicate that the response was incorrect.

2.1.21 Repetition

Lyster and Ranta (1997: p. 48) and Panova \&Lyster, (2002, p.584) state that repetition is “... the teacher's repetition, in isolation, of the student's erroneous utterance". In most cases, teachers adjust their intonation so as to highlight the error. As stated previously, Harmer (1991:63) uses the term "echoing" for "repetition" and he stresses that "Echoing", in its various forms, is probably the most efficient way of showing incorrectness."

\subsubsection{Denial}

Denial, as Harmer (1991:63) writes, is that type of oral feedback that occurs when the teacher tells the student that his/her response was incorrect and asks him/her to repeat it. He adds that this technique is "potentially discouraging" to students compared to other types of oral corrective feedback techniques hence teachers are advised to be very careful using this technique.

2.1.23 Questioning (Self- correction \& Peer-correction)

Oral corrective feedback could be in the form of guiding questions (Cohen, 1985; Harmer, 1991; Sales, 1993; Smith \& Ragan, 1993). Through questioning, the teacher may allow for both types of correction: self-correction and peercorrection. Long (1977) uses the term "error feedback" to refer to teacher's cues or hints, in this case questions, which are given to learners to encourage self-correction. Self-correction may happen when students are allowed to correct themselves instead of the teacher or their peers. When teachers allow for self-correction, they may target the students who committed the mistakes with a question like "Is that correct, Ahmed?" Through questioning, self-correction can be very beneficial for students. Makino (1993) states that:

"In the process of language learning, learners sometimes notice some of their errors by themselves, through the strategy of monitoring, and they can also correct some of their errors when other people, such as teachers ..., give them cues or hints about them. Those learners who are able to correct their own errors can activate their linguistic competence (that is, linguistic knowledge). " (p:338).

There are, however, a number of problems with learner self-correction. First, learners typically prefer the teacher do the correction for them. Second, and more importantly, learners can only self-correct if they possess the necessary linguistic knowledge. That is, in Corder's (1967) terms, they can correct their "mistakes" but not their "errors." Other (typically teacher) correction will be necessary to enable learners to identify forms that are not yet part of the interlanguage. Third, although output-prompting CF strategies signal that there is some kind of problem with the learner's utterance, they do not make it clear that the problem is a linguistic one (as opposed to just a communicative one).

Thus, there are clear grounds (theoretical and practical) for encouraging self-correction, but this will not always be possible, as indeed methodologists such as Hedge acknowledge. This presents teachers with a puzzle - should they push the learner to self-correct or provide the correction directly themselves? One solution sometimes advocated to this problem is to conduct $\mathrm{CF}$ as a two-stage process: first encourage self-correction and then, if that fails, provide the correction. This was the approach adopted by Doughty and Varela (1998).

On the other hand, peer-correction is an idea that was introduced by many researchers like Brown (2001), Hadley (2003), and Murphy (1986). Murphy (1986) thinks that peer-correction is a very effective feedback technique in which teachers involve their students in the responsibility of correction and feedback. Block (1996) supports the idea that peercorrection maybe more likely to promote students' learning as he suggests that “...it would appear that teachergenerated discourse is less memorable than student-generated discourse" (p: 170). But, Harmer (1991) disagrees with those who totally support peer-correction as he warns that in case of using such a technique, the student who made the mistake will feel exposed in front of his/her classmates. An example of peer-correction would be when the teacher asks some questions like "Is that correct?" which allows any student in the classroom to answer.

Finally, the disagreements regarding the relative efficacy of different CF strategies have motivated a number of experimental studies. Russell and Spada (2006) conducted meta-analysis of studies that have investigated the effects of different CF strategies on acquisition. This analysis demonstrated that CF is effective in promoting acquisition (the mean effect size for the fifteen studies they included in their analysis was 1.16), but they were unable to reach any conclusion regarding the relative effectiveness of different strategies due to insufficient studies meeting the requirements of a meta-analysis.

However, in a more traditional narrative survey of the research, Ellis, Loewen, and Erlam (2006) concluded that (1) both types of $\mathrm{CF}$, implicit and explicit, assist acquisition and (2) explicit $\mathrm{CF}$ is generally more effective than implicit. Their own study of the effects of recasts and metalinguistic explanation on the acquisition of past tense -ed supported (2); that is, metalinguistic explanation proved more effective. Other recent studies on oral CF (e.g., Lyster, 2004; Ammar \& Spada, 2006) have shown that output-prompting strategies are more effective than recasts (an inputprompting strategy). These studies suggest that it might be possible to identify those oral CF strategies that are generally the most effective, but caveats will inevitably arise as to whether they will prove the most effective with all learners in all contexts. 
2.2 The Impact of Oral Corrective Feedback

According to Birdsong, 1989; Bely- Vroman 1989; Gass, 1988a; Schachter, 1989 cited in Gass1997, oral corrective feedback is a necessary condition for second language learning. Researchers are in an agreement that oral corrective feedback helps students to change their false hypotheses and it also helps students in some cases of over-generalization (Bely- Vroman, 1986; Carrol\& Swain, 1993; Chaudron, 1977; Rutherford, 1987; White, 1989, 1991 cited in Nassaji\& Swain, 2000; Alvarez Sanches, 1982). An action research conducted over four years in 15 countries by Ancker (2000) on oral corrective feedback shows that teachers, teacher trainees and students think that although error correction might have a negative impact on students' confidence, it enhances learners to speak English correctly.

Furthermore, Arrowsmith (1988; cited in Harmer 2001) explains that the effect of correcting students' errors would probably depend on the type of student we deal with. It might decrease the motivation of weak students

while it might increase students' motivation. In line with that, Havranek \& Cesnik (2001)has tested the success of oral corrective feedback and found that it is affected by three factors:

(1) The format of oral corrective feedback,

(2) The type of error being corrected,

(3) Some student characteristics, among the most crucial are verbal intelligence, relative proficiency (within levels at school or university), and the student's attitude towards correction.

Teachers need to be very careful and diagnostic to individual teaching situations. They need to have a sufficient knowledge about their students' characteristics as well as to know the type of error they are dealing with in order to provide individual students with the most efficient and appropriate format of oral corrective feedback.

\subsection{Oral Corrective Feedback: Some Possible Obstacles and Drawbacks}

Unfortunately, there are some problems with giving oral corrective feedback: how to focus on both the content and the form of what students say, and how to create a balance between different types of feedback, as teachers tend to use certain corrective feedback heavily neglecting the other types (Lyster, 1998 cited in Gattullo 2000). Thornberry (1996) agrees with the first point reporting that the analysis of classroom discourse shows that teachers concentrate on the form of the students' language rather than listening to the content of what they are saying. This could be attributed to the feelings that many English teachers share that it is often difficult to pay attention and give feedback on both the content and the form of what students say. They feel that creating a balance is not achievable by all teachers and that only very creative teachers could have the experience and ability to do so.

An additional point to consider about oral corrective feedback is whether to correct all the errors done by students or to be selective. Updated theory on errors and correction supports the position that teachers should not correct every single error made by students and those which we correct, we should not correct immediately (Ancker, 2000).

Moreover, the idea of leaving some errors uncorrected might be very beneficial. Gattullo (2000) asserts that students tend to self-repair their errors and to negotiate with their teacher when the teacher does not provide them with the correct form of the target language. Vygotsky (1978, 1986 cited in Nassaji \& Swain 2000) agrees with this to some extent as he believes that corrective feedback should not be detailed as we should leave a space for students to think deeply to come up with solutions instead of giving them everything.

2.4 When and How to Provide Oral Corrective Feedback

When providing oral corrective feedback, as Ur (1996: 246) indicates,

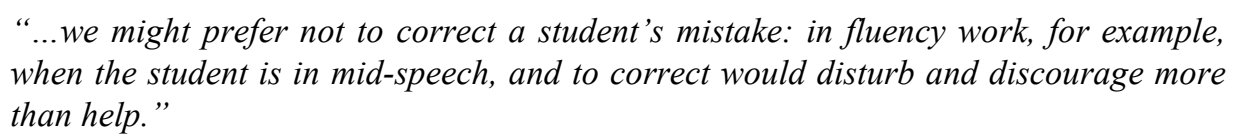

Lewis (2002) agrees that teachers should not always give oral corrective feedback during oral activities especially when the aim is to develop fluency and they should directly judge and evaluate grammatical and lexical errors when they aim to develop accuracy. Thus, Harmer (2001) indicates that, teachers should choose the key place or moment in the lesson to provide their feedback. For example, teachers should not provide their oral feedback during the communicative task to illustrate students' grammatical or lexical errors. However, Ellis (2009) points out that some SLA researchers argue that students should be provided with oral corrective feedback immediately after they have committed the errors for best effect. From the researchers' point of view, the choice of oral correction technique depends on the teaching situation. If the main focus is on fluency, it would be better to avoid some types of oral corrective feedback like explicit correction, repetition, recast, metalinguistic feedback and denial as these may hamper the flow of the students' speech. Other types like elicitation and clarification request could be used as these types might enrich the flow of speech and encourage students for further oral practice. On the other hand, if the main focus is on accuracy, then teachers may use any of the types of oral corrective feedback that they think appropriate.

Oral corrective feedback is usually provided directly by the teacher to the student who makes a mistake/mistakes during the lesson (Ur, 1996). There are different ways in which teachers can provide oral corrective feedback to their students either individually or in groups. Brown et al. (1998:25) suggest that "Face- to face [oral corrective] feedback can give pupils much more information than written feedback, through facial expression, tone of voice, body language." Moreover, Brown et al. (1998:25) not that "...it can be worth giving general feedback about common mistakes to group rather than individual." This might help other students to avoid that mistake in future. In addition to that and as Harmer (2001) points out, we should not always correct students in front of their classmates, especially the weak ones, to avoid frustrating them and to motivate students towards learning effectively. Hence the researchers think that both techniques of providing oral corrective feedback should take place in the classrooms. Teachers are usually advised to vary the techniques of providing oral corrective feedback they use and not to rely heavily on one technique. Teachers need to 
decide on the most appropriate technique to be used for particular correction situations and then reflect upon it. If teachers succeed in exposing students to receive and respond to individual and group oral corrective feedback they may serve two purposes: solving a current problematic situation (the error made by student/students) and expanding the students' learning experiences.

\subsection{Teachers' and Students' Preferences of Oral Error Correction}

Investigating both teachers' attitudes and students' attitudes toward oral error correction and other teaching issues could be very beneficial in education. A number of researchers of language learning (e.g., Green \& Oxford, 1995; Nunan; 1987; Schulz, 2001) found that creating a match between the preferences of both teachers and students is crucial for successful language learning. For example, Nunan (1987) argues that "one of the most serious blocks to learning is the mismatch between teacher and student expectations about what should happen in the classroom" (p.177). Researching students' attitudes, as some researchers believe, have been mostly neglected (Barkhuizen, 1998; Kumaravadivelu, 1991; MacBeath \&Mortimore, 2001; Rudduck, 1991). Rudduck (1991:3) refers to the neglecting of students' attitudes towards their teachers' teaching styles and manners as "our blind spot". Barkhuizen (1998) and MacBeath \& Mortimore (2001) support the idea of researching students' attitudes and think that it can be considered as a good source of information to teachers and others. Similarly, Horwitz (1988) believes that researching students' attitudes relevant to language learning can help teachers promote more effective learning strategies in their students. Nunan (1995) is also a supporter of this view as he writes "teachers should find out what their students think and feel about what and how they want to learn" (p.140). One key factor to language learning, as the researcher believes, is the participation of the students in the learning and teaching processes. Teachers need to put into practice the information they gathered about their students' preferences on how they want to learn.

Like any other issue in the field of education, teachers and their students have their own points of view and attitudes regarding oral error correction. These may vary from one context to another and so it is expected to find agreements in some cases and circumstances and disagreements in other cases and circumstances. Gregerson (2003) believes that some students find oral error correction distracting and demotivating, and it might also cause some stress to students. $\mathrm{He}$ also highlights that students are also inhibited by some oral error corrections. In order to overcome these possible obstacles of oral error correction, Diab (2006) advises teachers and students to work cooperatively in a supportive classroom atmosphere in which they understand the purpose behind different correction techniques and agree upon their use. If they succeed in doing that, he thinks that, this will lead to producing a fruitful work.

A number of studies have been conducted to find out teachers' and students' preferences of feedback and error correction. Some of which showed some differences and in some cases conflicts between the preferences of teachers and their students (Kern, 1995; Nunan, 1988; Schulz 1996, 2001). For example, Ancker (2000) as in his survey, in which he examined teachers' and students' expectations of error correction, he found that $25 \%$ of 802 teachers and $76 \%$ of 143 students believed that all errors should be corrected. The most frequent reason given by students in this study for wanting correction was the importance of learning to speak English correctly while the most frequent reason given by teachers for not wanting correction was the negative impact of correction on students' confidence and motivation. The results of this study go, line by line, with another study presented by Nunan (1993) in which he examined the relationship between the attitudes of students and teachers to a range of activities. The data of this study show a clear mismatch between students' and teachers' views in almost all activities. It also shows that error correction is very crucial from students' point of view as it got 7 out of 10 points among students, while for teachers it was of a very low priority as it got only 2 points. The big gap between students' point of view and teachers' point of view in Nunan's study might indicate that each of them set their own priorities based on how they look at things and how they think things should go. In real life, it is normal to find opposing points of view between different groups of different characteristics. Trying to make the gap between the points of view of teachers and students as small as possible would hopefully work for the teaching-learning process.

The following section gives more insight into the relationship between teachers' attitudes and practice. 2.6 Teachers' Attitudes and Practices

Although there seems to be some agreement that there is some sort of relationship between attitudes and practice (Borg, 1999; Burns, 1992; Schulz, 2001), it is believed that attitudes and practice do not always match (Burns, 1992). "The findings of some studies (e.g., Cathcart \& Olsen, 1976; Karavas-Doukas, 1996; McCargar, 1993; Nunan, 1988; Oladejo, 1993; Schulz, 1996, 2001) show mismatches between teachers' views and practices" (Katayama, 2006, p.1248). For example, in Karavas-Doukas' study in which he observed 14 Greek English language teachers' classroom practices, he found that although these teachers claimed to have positive attitudes towards Communicative Language Learning (CLT), their classroom practices differed considerably from the principles of the communicative approach. These teachers followed their own eclectic approach in which they used a combination of both traditional and communicative approaches in their lessons. This shows clearly the contradiction between their attitudes and their actual classroom practices (Karavas-Doukas, 1996). Basturkmen, Loewen, \& Ellis (2004) also carried out a study in which they looked at the relationship between teachers' views and their practices. Supporting what has been said earlier, this study also revealed a weak link between the views of the teachers under investigation and their actual practices.

The mismatch between teachers' attitudes and their classroom practices may occur for different reasons (Kagan, 1992). Some writers, like Breen et al (2001) and Burns (1992), proposed that the mismatch between teachers' attitudes and their practice might be due to some situational demands and constraints, practical considerations and the specific relationship between the teachers and their students. Fang (1996) also supports that teachers' practice might differ from 
their attitudes because "... their actual instructional practices [are] governed by the nature of instruction and classroom life" (p: 53).

\section{Conclusion}

Corrective feedback is one of the major issues in the domain of error correction. This research elucidated different types of techniques. It reviewed and recapitulated the experimental and theoretical surveys on this area of language teaching. The research is intended to illuminate the significant role that corrective feedback has in triggering learners to notice the gap that exists between their ill-formed speech and the target forms. In response to the dilemma of error correction, it can be stated that leaving students' errors untouched might lead to the fossilization of ill-formed structures. Therefore, corrective feedback can be used as an effective technique in eliminating possible non-target-like utterances in the learners' interlanguage. The discussion has highlighted that different writers consider different areas, when they talk about the role of oral feedback in language learning. They also look at the significance of oral feedback from different perspectives. The discussion also has shown that although oral corrective feedback is a major issue for second language learning, there are some problematic areas with oral correction. The discussion also has revealed that a number of studies that have been done found a mismatch between teachers' and students' preferences for oral correction as well as between teachers' attitudes and practices. Error correction is needed to improve learners' performance, but teachers' timely interference in their students' learning process is very crucial to enhance their language education and leave positive effect.

\section{References}

Alvarez Sanchez, A. (1982). Are we correcting or "Killing” our Students? English Teaching Forum, xx (3), 43-44.

Ammar, A., \&Spada, N. (2006). One size fits all? Recasts, prompts and L2 learning. Studies Second Language Acquisition, 28, 543-574.

Ancker, W. (2000). Errors and Corrective Feedback: Updated Theory and Classroom Practice. English Teaching Forum, 38 (4), 20-25.

Askew, S. (2000). Feedback for Learning. London: Routledge.

Askew, S. \& Lodge, C. (2000). Gifts, ping-pong and loops-linking feedback and learning. In Askew, S. (Ed.). Feedback for Learning. London: Routledge

Barkhuizen, G. (1998). Discovering learners ${ }^{e e}$ perceptions of ESL classroom teaching/learning activities in South African context. TESOL Quarterly, 32 (1), 23- 40.

Basturkmen, H., Loewen, S., \& Ellis, R. (2004). Teachers ${ }^{\text {ee }}$ stated beliefs about incidental focus on form and their classroom practices. Applied Linguistics, 25(2), 243-272.

Birdsong, D. (2006). Age and second language acquisition and processing: A selective overview. Language Learning, $56,9-49$.

Block, D. (1996). Window on the classroom: classroom events viewed from different angles, in Bailey \&Nunan: 168 194.

Borg, S. (1999). Teachers ${ }^{e e}$ theories in grammar teaching. English Language Teaching Journal, 53(3), 157-167.

Braidi, S. (2002). Reexamining the role of recasts in native speaker/nonnative-speaker interactions. Language Learning, 52(1), 1-42.

Breen, M., Hird, B., Milton, M., Oliver, R., \&Thwaite, A. (2001). Making sense of language teaching: Teachers ${ }^{\text {ee }}$ principles and classroom practices. Applied Linguistics, 22 (4), 470-501.

Brown, H. (2001). Teaching by principles. New York: Pearson Education Company.

Burns, A. (1992). Teacher beliefs and their influence on classroom practice. Prospect, 7 (3), 55-66.

Burt, M. K. (1975). Error analysis in the adult EFL classroom. TESOL Quarterly, 9, 1, 53-63. http://dx.doi.org/10.2307/3586012.

Cameron, L. (2001). Teaching Languages to Young Learners. Cambridge: Cambridge University Press.

Carroll, S. \& Swain, M. (1993). Explicit and implicit negative feedback: An empirical study of the learning of linguistic generalizations. Studies in Second Language Acquisition, 15(3), 357-386.

Cathcart, R., \& Olsen J. (1976). Teachers ${ }^{\text {ee }}$ and students ${ }^{\text {ee }}$ preferences for correction of classroom conversation errors. TESOL, 76, 41-45.

Chambers, G. (1999). Motivating Language Learners. Great Britain. WBC Book Manufacturers Ltd.

Chaudron, C. (1977). A descriptive model of discourse in the correctional treatment of learners ${ }^{c e}$ errors. Language Learning, 27, 29-46.

Cohen, V. (1985). A reexamination of feedback in computer-based instruction: Implications for instructional design. Educational Technology, 25(1), 33-37.

Corder, S. (1967). The significance of learners' errors. International Review of Applied Linguistics, 4, 161-170.

Coulthard, M. (1992). Advances in Spoken Discourse Analysis. London: Routledge. 
Dempsey, J. V., Driscoll, M. P., \&Swindell, L. K. (1993). Text-based feedback. In J. V. Dempsey \& G. C. Sales (Eds.), Interactive instruction and feedback (pp. 21-54). Englewood Cliffs, N.J.: Educational Technology Publications.

Diab, R. (2006). Error correction and feedback in the EFL writing classroom: Comparing instructor and student preferences. English Teaching Forum, 44(1), 2-13.

Doughty, C., \& Varela, E. (1998). Communicative focus on form. In C. Doughty \& J. Williams (Eds.), Focus on form in classroom second language acquisition (pp. 114-138). New York: Cambridge University Press.

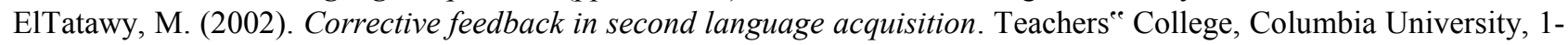
19.

Ellis, R. (1993). Second language acquisition and the structural syllabus. TESOL Quarterly, 27, 91-113.

Fang, Z. (1996). A review of research on teacher beliefs and practices. Educational Research, 38(1), 47-65.

Fanselow, J. (1977). Beyond Rashomon: Conceptualizing and observing the teaching act. TESOL Quarterly, 11(1), 1741.

Farrar, M. J. (1992). Negative evidence and grammatical morpheme acquisition. Developmental Psychology, 28, 90-98. Gass, S. M. (1988a). Second language vocabulary acquisition. Annual Review of Applied Linguistics, 9, 92-106.

Gattullo, F. (2000). Corrective Feedback and Teaching Style: Exploring a relationship. In Moon and Nikolov (eds.). Researching into English Teaching for Young Learners. Pecs: University of Pecs Press, 295-311.

Green, J. and Oxford, R. (1995). A closer look at learning strategies, L2 proficiency, and gender. TESOL Quarterly, 29, 261-297.

Hadley, A. (2003). Teaching language in context. 3rd ed., Heinle\&Heinle Publishers.

Hamp-Lyons, L. and Heasley, B. (1987). Study Writing: A course in written English for academic and professional purposes. Cambridge: Cambridge University Press.

Han, Z. (2002a). Rethinking the role of corrective feedback in communicative language teaching. RELC Journal, 33(1), $1-33$.

Harmer, J. (1991). The Practice of English Language Teaching. Harlow: Longman.

Havranek, G. and Cesnik, H. (2001). Factors Affecting the Success of Corrective Feedback. EUROSLA yearbook, 1, 99-122.

Hendrickson, J. (1978). Error correction in foreign language teaching: Recent theory, research, and practice. Modern Language Journal, 62, 387-398.

Iwashita, N. (2003). Negative feedback and positive evidence in task-based interaction: Differential effects on L2 development. Studies in Second Language Acquisition, 25, 1-36.

Horwitz, E. (1988). The beliefs about language learning of beginning university foreign language students. The Modern Language Journal, 72, 283-294.

Kagan, D. (1992). Implications of research on teacher belief. Educational Psychologist, 27(1), 65-90.

Karavas-Doukas, E. (1996). Using attitude scales to investigate teachers' attitudes to the communicative approach. English Language Teaching Journal, 50(3), 187-198.

Kartchava, E. (2006). Corrective Feedback: Novice ESL Teachers' Beliefs and Practices. A Thesis in the Department of Education TESL Centre. Presented in Partial Fulfillment of the Requirements for the Degree of Master of Arts (Applied Linguistics) at Concordia University, Montreal, Quebec, Canada. March (2006), 1-125.

Katayama, A. (2006). Perceptions of JFL students toward correction of oral errors. In Bradford-Watts, K., Ikeguchi, C., \& Swanson, M. (Eds.) JALT2005 Conference Proceedings, Tokyo: JALT, 1248-1264.

Kern, R. (1995). Students' and teachers' beliefs about language learning. Foreign Language Annals, 28(1), 71-92.

Krashen, S. (1982). Principles and Practice in Second Language Acquisition. Oxford: Pergamon.

Kumaravadivelu, B. (1991). Language learning tasks: Teacher intention and learner interpretation. ELT Journal, 45 (2), 98-102.

Lasagabaster, D., \& Sierra, J. (2005). Error correction: Students' versus teachers' perceptions. Language Awareness, 14(2-3), 112-127.

Leeman, J. (2003). Recasts and second language development: Beyond negative evidence. Studies in Second Language Acquisition, 25(1), 37-63.

Lewis, M. (2002). Giving Feedback in Language Classes. Singapore: SEAMEO Regional Language Center.

Lightbown, P. \&Spada, N. (1999). How Languages are Learned. Oxford. Oxford University Press.

Lin, H. (2009). Patterns of Corrective Feedback and Learner Uptake in ESL Low, Intermediate, and Advanced Level Speaking Classrooms (PHD Dissertation). Alliant International University, San Diego.

Littelwood, W. (1981). Communication Language Teaching. Cambridge: Cambridge University Press.

Loewen, S. (2004). Uptake in Incidental Focus on form in Meaning-Focused ESL Lessons. Language Learning, 54 (1), 153-188.

Loewen, S. (2005). Incidental Focus-on-form and Second Language Learning. Studies in Second Language Acquisition, $27,361-386$. 
Long, M. (1977). Teacher feedback on learner error: mapping cognitions. In Brown, H. D., Yorio, C. A., \&Crymes, R. (eds.), On TESOL '77. Teaching and learning English as a Second Language: Trends in research and practice, 278-294. Lynch, T. (1996). Communication in the Language classroom. Oxford: Oxford University Press.

Lyster, R. \&Ranta, L. (1997). Corrective feedback and learner uptake: Negotiation of form in communicative classrooms. Studies in Second Language Acquisition. 19, 37-66.

Macbeath, J. \&Mortimore, P. (2001). Improving school effectiveness. Philadelphia: Open University Press.

Mackey, A., \&Philp, J. (1998). Conversational interaction and second language development: Recast responses, and red herring? Modern Language Journal, 82,338-356.

McCargar, D. (1993). Teacher and student role expectations: Cross-cultural differences and implications. The Modern Language Journal, 77(2), 192-207.

McDevitt, D. (1989). How to Cope with Spaghetti Writing. English Language Teaching Journal, 43(1), 19-23.

McNamara, E. (1999). Positive Pupil Management and Motivation: A secondary teacher's guide. London: David Fulton Publishers.

Mendez, E., Arguelles, L. \& Castro, A. (2010). Oral Corrective Feedback: Some Ways to Go About it. FEL International, 33(1), 254-270.

Morris, F., \&Tarone, E. (2003). Impact of classroom dynamics on the effectiveness of recasts in second language acquisition. Language Learning, 53, 325-368.

Murphy, D. (1986). Communication and Correction in the Classroom. English Language Teaching Journal, 40(2), 141151.

Nabei, T., \& Swain, M. (2002). Learner awareness of recasts in classroom interaction: A case study of an adult EFL student's second language learning. Language Awareness, 11, 43-63.

Nassaji, H. \& Swain, M. (2000). A Vygotskian Perspective on Corrective Feedback in L2: The effect of random versus negotiated help on the learning of English articles. Language Awareness, 9(1), 34-49.

Nelson, K. E., Denninger, M., Bonvillian, J. D., Kaplan, B., \& Baker, N. (1984). Maternal input adjustments and nonadjustments as related to children's advances and to language acquisition theories. In A. D. Pellegrini\& T. D. Yawkey (Eds.), The development of oral and written language in social contexts(pp. 31-56). Norwood, NJ: Ablex.

Nicholas, H., Lightbown, P. M., \&Spada, N. (2001). Recasts as feedback to language learners. Language Learning, 51, 719-758.

Nunan, D. (1987). Communicative language teaching: The learner"s view. In Bikram, K. (Ed.), Communication and learning in the classroom community, (pp. 176-190). Singapore: SEAMEO Regional Language Centre.

Ohta, A. S. (2001). Second language acquisition processes in the classroom: Learning Japanese. Mahwah, NJ: Lawrence Erlbaum.

Oladejo, J. (1993). Error correction in ESL: Learners"e preference. TESL Canada Journal, 10(2), 71-89.

Oliver, R. (1995). Negative feedback in child NS-NNS conversation. Studies in Second Language Acquisition, 17, 459481.

Panova, I., \&Lyster, R. (2002). Patterns of corrective feedback and uptake in an adult ESL classroom. TESOL Quarterly, 36(4), 573-595.

Perrott, E. (1982). Effective Teaching: a practical guide to improving your teaching. Harlow: Longman.

Philp, J. (2003). Constraints on 'noticing the gap': Normative speakers' noticing of recasts in NS-NNS interaction. Studies in Second Language Acquisition, 25, 99-126.

Richards, J \& Lockhart, C. (1994). Reflective Teaching in Second Language Classrooms. Cambridge. Cambridge Language Education.

Richardson, V., Anders, P., Tidwell, D., \& Lloyd, C. (1991). The relationship between teachers" beliefs and practices in reading comprehension instructions. American Educational Research Journal, 28(3), 559-586.

Rudduck, J. (1991). Innovation and change. Milton Keynes, England: Open University Press.

Russell, J. \&Spada, N. (2006). The effectiveness of corrective feedback for the acquisition of grammar: A meta-analysis of research .Amsterdam. John Benjamins Publishing.

Rutherford, W. (1987). Second language grammar: learning and teaching. London: Longman

Sales, G. (1993). Adapted and adaptive feedback in technology-based instruction. In Dempsey, J \& Sales, G (Eds.), Interactive instruction and feedback (pp. 159-175). Englewood Cliffs, N.J.: Educational Technology Publications.

Schachter, J. (1991). Corrective feedback in historical perspective. Second Language Research, 7, 89-102.

Schulz, R. (1996). Focus on form in the foreign language classroom: students' and teachers' views on error correction and the role of grammar. Foreign Language Annals, 29 (3), 343-364.

Sheen, Y. (2004). Corrective feedback and learner uptake in communicative classrooms across instructional settings. Language Teaching Research, 8, 263-300. 
Sinclair, J. \& Brazil, D. (1982). Teacher Talk. Oxford: Oxford University Press.

Smith, H. (2010). Correct Me if I'm Wrong: Investigating the Preferences in Error Correction Among Adult English Language Learners. (MA thesis 2010). University of Central Florida Orlando, Florida.

Tabatabaei, O. \&Banitalebi, A. (2011). Feedback Strategies in Foreign Language Reading Classes. Asian Culture and History, 3(2), 59-70.

Thornberry, S. (1996). Teachers Research Teacher Talk. English Language Teaching Journal, 50(4), 279-289.

Tsui, A. (1995). Introducing Classroom Interaction. London: Penguin.

Ur, P. (1996). A Course in Language Teaching. Cambridge: Cambridge University Press.

White, L. (1993). Adverb placement in second language acquisition: Some positive and negative evidence in the classroom. Second Language Research, 7, 122-161.

Wragg, E. \& Brown, G. (1993). Exploring. New York. Routledge.

Yoshida, R. (2008). Teachers' choice and learners' preference of corrective feedback types. Language Awareness, 17(1), 78-93. 